\title{
Teaching, Learning, and Understanding of Public History in Schools as Challenge for Students and Teachers
}

\section{Commentary}

History is a part of everyday life. We consume stories about the past in films, musicals, and lectures. We read historical fiction, create and consume memes, visit historical sites and museums, play historical games, and preserve and investigate family history. We seek out information to contextualize and understand the present. This everyday public history lives mostly independently from the history taught and learned in schools. What is the role of public history in schools? What are the challenges it presents in the history classroom? What are the opportunities it creates?

This set of essays originated with a Fall 2015 panel titled, "Public History in the Classroom: Teaching, Learning, and Understanding of Public History in schools as challenge for students and teachers." With speakers from Austria, Germany, South Africa and the United States talking about a relatively underexamined aspect of public history, the possibility of contrasting interpretations of our title and purpose was great. But this set of essays show that we shared some fundamental assumptions about our purposes and focus.

First of all, these papers discuss public history in the classroom, rather than as the classroom. There is an argument to be made that the pre-collegiate history classroom is a site of public history, but scholars still differ regarding this point. Is it a "blind spot" that the English-speaking conversation about public history does not include the teaching of history?" Or is public history partially defined by where it happens, i.e., "outside [of] academic settings"? ? While Arendes in

1 A special thanks to Public History Weekly and Marko Demantowsky for organizing this conference.

2 Marko Demantowsky, “Public history'- Sublation of a German Debate?,” Public History Weekly, 3 (2015) 2, accessed October 31, 2016, public-history-weekly.degruyter.com/3-2015-2/publichistory -sublation-german-debate/.

3 Serge Noiret, “Internationalizing Public History,” Public History Weekly, 2 (2014) 34, accessed October 31, 2016, public-history-weekly.degruyter.com/2-2014-34/internationalizing-public-history/; Thomas Cauvin, “Defining Public History. A Work in Progress. What Do You Think?,” accessed October 31, 2016, thomascauvin.com/uncategorized/defining-public-history-a-work-in-progresswhat-do-you-think/?platform=hootsuite. 
this collection addresses the problem of defining public history in the context of Germany universities, the larger debate need not be settled here nor is it the focus. ${ }^{4}$ Rather this set of papers focuses on public history as part of the curriculum rather than schools as sites of public history.

The authors also share an assumption that a central goal of any history curriculum is to understand history as a discipline, how it works and the conventions that it demands. Arendes talks about "a set of disciplinary standards," Kühberger talks about "train[ing] students in the skills of critical historical thinking" and Siebörger mentions "procedural knowledge" and "skills and concepts" as learning goals. Rather than only focus on the products of the discipline - the stories and arguments that historians produce - the scholars also value and prioritize learning historical thinking within the context of studying particular historical topics, questions, and problems.

\section{Students as Consumers of Public History}

Given a consideration of public history as curricula and historical thinking as learning goal, the authors here agree that public history belongs in the classroom. Kühberger calls our attention to the fact that students bring in public history regardless of whether educators intentionally make it part of the curriculum or not. Students know stories about the past and have mental pictures of aspects of the past from their everyday, outside of school, experiences. Whether it be the inaccurate idea that Vikings wore horned hats or knowing only a single triumphal story of the Great Trek in South Africa, students' prior ideas affect their learning. Researchers know that students use existing schema and prior knowledge to make sense of new information and concepts. ${ }^{5}$ Educators who ignore that students construct new understandings and knowledge using what they think they already know do so at their own peril.

4 Peter Seixas, “A History/Memory Matrix for History Education,” Public History Weekly, 4 (2016) 6, accessed October 31, 2016, public-history-weekly.degruyter.com/4-2016-6/a-historymemorymatrix-for-history-education/. Seixas offers an important perspective on how collective memory and disciplinary practices overlap in the classroom.

5 John D. Bransford, Anne L. Brown, and Rodney R. Cocking, eds., How People Learn: Brain, Mind, Experience, and School (Washington, D.C.: National Academy Press, 2000); Richard Anderson, "The notion of schemata and the Educational Enterprise: General Discussion of the Conference," in Schooling and the Acquisition of Knowledge, ed., Richard C. Anderson et al. (New Jersey: Erlbaum, 1977), 415-432. 
Given the ubiquity of historical references and stories in national and regional popular cultures, it behooves local educators and researchers to consider, what Kühberger calls, society's cultural inventory of public history interpretations. He asks us to consider that such an inventory would find that these interpretations not only include types that are most common in history education discussions and research such as films, museums, and historical novels but also types that are often overlooked such as computer games, comic books, re-enactments, and even toys and games. He also urges us to consider the variety of private uses of public history and that different students will encounter different representations of history in their private lives, creatively proposing ethnographies of young children's bedrooms as one way to access those variations and representations.

The variety of historical representations that students encounter, explore and internalize outside of school pose a significant challenge to the educator. Educators will need to consider which representations have had the greatest impact on significant numbers of their pupils in regards to the existing curriculum, and access and uncover students' thinking about particular representations.

\section{Curricular Approach - Students as Critical Consumer}

Yet, intentional inclusion of some public history in the curriculum may also offer opportunities that help navigate these challenges. Teachers can use these popular stories and representations purposefully to accomplish significant learning goals. Consider a First Encounter story of Pocahontas and John Smith in the early days of the Jamestown colony in what is now the state of Virginia. A story popularized in the United States by Disney films depicts the Powhatan Indian princess Pocahontas and the English colonist John Smith as an romantic couple who are brought together by Pocahontas' daring rescue of Smith from a tribal beheading. The film tells a moralistic, tidy story that follows a familiar and triumphal narrative arc. Bringing this public history story into the classroom allows U.S. educators to make visible and teach how the discipline of history works. A lesson guided and framed by the question "Did Pocahontas rescue John Smith?” has students start with what they think they know and how they know it (i.e., Disney films), then move to investigating successive rounds of primary and secondary sources ${ }^{6}$

6 Peter Seixas, “Translation and it’s discontents: key concepts in English and German history education,” Journal of Curriculum Studies. DOI:10.1080/00220272.2015.1101618. 4. Secondary 
directly related to this supposed rescue. ${ }^{7}$ As students do source work, their prior "knowledge" about this encounter is challenged. Debriefing this learning experience with students allows teachers to make explicit key tools and processes for reconstructing the past and the interpretive, evidence-based, and complex nature of history.

Students too frequently see history as a single story that is certain and complete. Directly challenging a story they think they know can puzzle and perplex them, prompting them to ask questions. This, in turn, can open doors to learning how history works. Curricula such as this Pocahontas lesson, a "what is history" lesson, facilitate this, ${ }^{8}$ and its focus on a public history narrative is part of its success. Using a story that is well known by many students from their experiences outside school means that many are engaged with the lesson from the start and interested in the challenge. Additionally, evaluating such stories means that students are working with and questioning secondary, rather than primary, sources. This is important because as Kühberger points out students encounter secondary sources much more frequently in their everyday lives than primary sources.

Including public history stories in the history curriculum in intentional ways can open up engaging opportunities for students to critically analyze familiar historical narratives and representations, and learn more about how the past is reconstructed. Students become critical consumers of historical narratives constructed for a popular audience. Given that these public narratives frequently are shaped by agendas that do not value the completeness, multiperspectivity, or contingency of the story as highly as a message they wish to promote or sell, could their use be more productive in fostering historical thinking and critical analysis than more staid or accurate narratives?

Rob Siebörger's discussion of two case studies of South African curricula make clear that it is not that simple. His analysis of how the Great Trek narrative was enacted in the curriculum and the absence of Robben Island from that curriculum shows the importance of the choice of public history narratives to teach and of the instructional approach to any such narrative.

sources "narrate or explain from a position later than the time that is under study," and primary sources are those that are produced during the time under study.

7 Sam Wineburg, Daisy Martin, and Chauncey Monte-Sano, Reading Like a Historian: Teaching Literacy in Middle and High School Classrooms (New York: Teachers College Press, 2013), 1-16.

8 Denis Shemilt, 13-16 Project Evaluation (Edinburgh: Holmes McDougall, 1980); Robert B. Bain, "Into the Breach," in Knowing, Teaching and Learning History: National and International Perspectives, eds., Peter N. Stearns, Peter Seixas, and Sam Wineburg (New York: New York University Press, 2000), 336-340; Wineburg, Martin, and Monte-Sano, Reading Like a Historian, 6. 
The story of the Great Trek, a "key narrative of the state" during apartheid, was popularized both through "similar repetition" in the school curriculum and outside celebrations and representations. In school, students studied an overly heroic, triumphant story of the Great Trek in multiple courses and the content of that study changed little except to add additional information and specifics about the event. Missed were opportunities to frame the story in different ways or engage students in analyzing the narrative using progressively sophisticated historical thinking. Public history in the curriculum in this case meant "conformity and sameness," "shallow interpretations," and "rote memorization of the deeds of heroes." Similar repetition over multiple years meant that a single dominant narrative essentially colonized the curriculum. This curricular approach essentially valued a heritage approach to studying the past rather than an historical approach. ${ }^{9}$

Heritage, in David Lowenthal's scheme, is more interested in a worship of the past than a careful reconstruction or critical interrogation of it. The essential aim of heritage stories is a "prejudiced pride in the past," and building unity, identity and "civic allegiances" from shared, mythological stories. ${ }^{10}$ Those stories are "immune to conscious revision" and thrive on "formulaic repetition."11 Heritage stories deliberately celebrate some aspects of the past while entirely omitting others. Siebörger's analysis of the case of Robben Island, an island that served as prison for black political prisoners, shows how a heritage focused curriculum holds no space for particular aspects of the past - in this case, the politics of black resistance to the state. In a heritage approach, public history narratives in the curriculum become a way to promote particular messages about the past that serve present interests, and critique of those heritage stories may be risky or condemned. Putting students in the role of critical consumer of such a story is a qualitatively different move than questioning a story mostly crafted for entertainment and business purposes such as the Pocahontas and John Smith interaction. As educators and researchers think about selecting popular representations to interrogate for the school curriculum, these differences will need to be considered.

Siebörger's analysis of these two curricular topics and changes to the school curriculum highlights additional practical considerations for situating students as critical consumers of public history narratives. He indicates that the existence of multiple sources and narratives relevant to an historical phenomenon matter

9 David Lowenthal, "Fabricating Heritage," History and Memory 10, no. 1 (1998), 5-24.

10 Ibid., 3, 4.

11 Ibid., 18. 
to its curricular potential, and notes that these do indeed exist for both the Great Trek narrative and a study of Robben Island. The latter also offers opportunities to study the content of political and social activism and the traces left behind by activists and ordinary people rather than only political leaders. Siebörger also cautions against the assumption that all public history is engaging for students and points out that similar repetition and the content of that study matter to that engagement.

\section{Curricular Approach - Students as Reflective Producers}

Situating students as producers of knowledge is another approach to including public history in the curriculum. In this role, students create their own representations of the past, such as memorials, museum exhibits, and historical plaques. These kinds of projects require that students do thinking similar to what they do in the consumer role (e.g., analyze multiple sources, harness background information); but, they also require that students make the necessary choices involved in creating consumable historical interpretations and narratives for an audience outside school.

Arendes, in his essay, advocates for a students as producers approach being at the heart of a university program in public history. He asserts that project related teaching should be the focus of this curriculum and that students should have "authentic experiences in research." Students would develop their own research interests and questions, conduct independent research, and then, rather than only producing a paper for their professor, consider how to communicate their findings to a public audience in a particular format. The subsequent and final step would be to reflect on the limits and difficulties in crafting that public communication and knowledge transfer. These final processes - presenting research to a non-expert audience outside of the academy and required reflection - add two steps to the production of historical knowledge that go beyond the demands of a typical university based study of history. This set of working processes is one concrete, specific way that the study of public history can, as Arendes proposes, break down traditional boundaries between scholarship and practical application.

Making the doing of public history projects central to the training of public history university students makes sense as this curricular approach essentially apprentices these students into public history's craft and study. But producing public history is not only for public history university students, it is a promising curricular approach for other educational contexts as well. 
Consider the lab-based experience where students co-constructed an exhibiton a local event that one history teacher educator required.12 Professor Linda Sargent-Wood designed a project that required teacher candidates to create an interpretive sign to explain the 1928 disappearance of a honeymooning couple in nearby Grand Canyon National Park. The project included researching the event and then having to make choices about how to represent the mysterious story to the public on an interpretive sign. This was a group project and the professor chose the topic, but it demanded similar processes to those Arendes identifies, including research and translation of that research for a public audience.

High school students can also become producers of public historical representations. In People Need to Know: Confronting History in the Heartland, researcher Rob Lucas described and investigated one teacher's local "Community History Project." 13 This project, a partnership between the local public high school and library, was a key part of the teacher's curricula for more than a decade. Students selected local research topics, investigated those topics, and then presented their findings in a public product. These products included oral histories, essays for the local library's archives, web pages, and videos, and addressed many aspects of the local past, including the focus of Lucas' study, one particularly horrendous event, a mob lynching in 1930. In designing this curriculum, this teacher rejected the idea of the "disposable project," or one intended only for classroom use, in favor of products with public value. Students worked to create consequential products that local community audiences could learn from. Lucas' analysis shows that in projects such as this one, creating work of public value becomes an important learning goal for the activity. Additionally, the question - what should we contribute? - becomes part of the process of designing the curriculum and one that can be addressed collaboratively by teachers and students. ${ }^{14}$ (Arendes points out that even identifying the research questions can be a collaborative activity between the outside community and students.) In integrating the production of public history into the school curriculum, students not only potentially learn aspects of communicating and constructing the past, but they also work on products that hold real value outside school.

Frequently students, if expected to create interpretations at all rather than parrot existing ones, usually do so for class credit and only the teacher's eyes. An authentic audience means that students must meet a higher bar - they must

12 Linda Sargent Wood, "Hooked on Inquiry: History Labs in the Methods Course," History Teacher 45, no. 4 (2012): 549-567.

13 Robert M. Lucas, People Need to Know: Confronting History in the Heartland (Washington D.C.: Peter Lang Publishing, 2016).

14 Ibid., 45. 
argue and explain for a more diverse, and likely less informed, audience than their teacher. They must meet particular purposes such as education as well as historical accuracy and audience engagement. Producing public history allows for more learning about how audience and purpose matter to interpretive stances and narratives.

Producing public history artifacts also can, as these authors point out, integrate local, regional, and place-based stories into the curriculum. The Community History Project and teacher education project both require that students investigate the local past. Moving the lens from routinely beginning with national history to starting with local or regional pasts may be more interesting for students. It also opens up opportunities to help students understand the issue of scale in history, an important analytic historical approach. ${ }^{15}$ Students face questions such as, What is the significance of this historical phenomenon, (i.e., person, place, event), for local, regional, national audiences? How does it fit into larger regional or international stories? Partnerships between local and regional public history organizations (e.g., museums, parks, historical associations) and the school both facilitate these kinds of projects and are supported by them.

And in producing public history, the existence and challenge of the heritage/history divide rise to the top of the work. Siebörger's South African case studies demonstrate the tendency for public history to focus on boosterism and a simplified, glorified and sanitized past - in other words a heritage approach. Producing public interpretations of the past thrusts students into this quandary of how to remember the past, what and whose story (or stories) to tell, and the purposes of that telling. Within a curriculum absent public history projects, students have to strive for historical accuracy and completeness but the political and social implications of their interpretive decisions, the necessity of communicating with a broader audience - these aspects of representing the past are less salient. Taking students through Arendes' "common working processes" of public history that includes both communicating historical knowledge and interpretation to a general audience, and reflecting on this communication make these tensions and choices explicit and unavoidable. Students potentially learn that different purposes shape how we represent the past and recognize existing tensions between scholarly products and public history products.

15 Robert B. Bain and Lauren McArthur Harris, Preface to This Fleeting World: A Short History of Humanity, by David Christian (Massachusetts: Berkshire Publishing Group, LLC, 2008), $\mathrm{ix}-\mathrm{xv}$. 


\section{Public History Lessons - Summary and Conclusion}

The papers in this collection suggest that situating students as producers or consumers of public history brings specific teaching and learning opportunities into the classroom. These include building on, and critiquing what students encounter outside school, and incorporating more secondary sources into the curriculum thereby facilitating students' understanding of how those types of sources work. Public history in the school curriculum may offer additional engagement and learning advantages given its frequent connections to place, and that students create representations with public value for a real audience. Curricula where the student becomes a skeptical consumer of historical narratives or a producer of purposeful public histories allow students to build skills of historical thinking, while delving deeply into particular historical topics and questions.

But whenever we talk about the contents of the school curriculum, certain challenges loom - the first being the fact of limited space in that curriculum. Instructional time is always at a premium in the history classroom. Is public history more worthy than other curricular topics and approaches? And if it is worth it, what public history topics should be used? Kühberger shows us that different students are familiar with different public representations - which ones should be included to meet teaching goals most effectively? Siebörger calls attention to a concern that time for studying national history is reduced if local and regional public history is included in the curriculum. These kinds of choices and concerns undoubtedly arise in decisions about what students will study in the classroom. And however they are navigated and resolved, engaging students in investigating and producing public history is necessarily contingent and dependent on teacher knowledge and available instructional materials and resources important factors in the success of any curricular change.

Incorporating public history into the school curriculum also brings specific challenges that go beyond these general challenges of time, selection, teacher knowledge, and instructional materials. Our collective memory stories, our museums, memorials, monuments, and myths matter to us. And the truth of those stories is not necessarily a community's primary concern, it is the emotional connection, the group identity and pride, and the lessons that these representations provide that is valued most. Question the American story of Thanksgiving as a unifying event where Pilgrims and Indians became partners in the New World? Question the story of the dropping of the atomic bomb as necessary to ending World War II? Such questioning is not taken lightly nor routinely welcome outside the academy. The emotional connections and the satisfaction we get from public history representations and heritage stories is heartfelt and significant. 
But what this means is that any inclusion of public history must be done in the context of a curriculum that values and prioritizes the teaching and learning of historical thinking and disciplinary competencies. Otherwise the risk in inserting heritage stories is that memorizing, or at best the skilled retelling, of those stories becomes the goal of history education. "Formulaic repetition" could dominate and then rather than discussing public history in the classroom as these papers do, the conversation needs to shift to focus on the classroom as a site of public history.

It is also precisely because of this risk that given a curriculum aimed at teaching historical thinking, public history should be a necessary part of the curriculum. Rather than hide from students these contrasting ways of approaching the past (i.e., heritage versus history), make them explicit and students can learn more about the differences between representing the past for truthful or mythic purposes.

Ultimately, including public history intentionally and thoughtfully in the school curricula is partly necessary to prepare students to wisely navigate and consider the multitude of representations of the past that they will encounter outside of school in their futures. Through well-designed lessons, students can learn to be critical consumers of the easy story and ask probing questions of interpretations related to purposes and audiences, evidentiary warrants, and missing voices and perspectives. One can teach historical thinking without explicitly addressing public representations of the past, but the curricular potential of using or creating those representations is too great to ignore. Siebörger tells us that "History curriculum designers need to pay far more attention to the dialectics of the relationship between curriculum content and topics and public history, in all its manifestations." This set of papers is a step in that direction.

\section{Literature cited}

Anderson, Richard. The notion of Schemata and the Educational Enterprise: General Discussion of the Conference. In Schooling and the Acquisition of Knowledge, edited by Richard C. Anderson, Rand J. Spiro, and William E. Montague, 415-432. New Jersey: Erlbaum, 1977.

Bain, Robert B. and Lauren McArthur Harris. Preface to This Fleeting World: A Short History of Humanity, by David Christian, ix-xv. Massachusetts: Berkshire Publishing Group, LLC, 2008.

Bain, Robert B. Into the Breach: Using Research and Theory to Shape History Instruction. In Knowing, Teaching and Learning History: National and International Perspectives, edited by Peter N. Stearns, Peter Seixas, and Sam Wineburg, 331-353. New York: New York University Press, 2000. 
Bransford, John D., Anne L. Brown, and Rodney R. Cocking, eds. How People Learn: Brain, Mind, Experience, and School. Washington, D.C.: National Academy Press, 2000.

Cauvin, Thomas. Defining Public History. A Work in Progress. What Do You Think?. Accessed October 31, 2016. thomascauvin.com/uncategorized/defining -public-history-a-work-inprogress-what-do-you-think/?platform = hootsuite.

Demantowsky, Marko. Public history'- Sublation of a German Debate?. Public History Weekly 3 (2015) 2. Accessed October 31, 2016. public-history -weekly.degruyter.com/3-2015-2/ public-history-sublation-german-debate/.

Lowenthal, David. Fabricating Heritage. History and Memory 10, no. 1 (1998): 5-24.

Lucas, Robert M. People Need to Know: Confronting History in the Heartland. Washington D.C.: Peter Lang Publishing, 2016.

Noiret, Serge. Internationalizing Public History, Public History Weekly -The International Blogjournal, 2 (2014) 34. Accessed October 31, 2016. public -history-weekly.degruyter. com/2-2014-34/internationalizing-public-history/

Seixas, Peter. Translation and its discontents: key concepts in English and German history education. Journal of Curriculum Studies 48 (2015): 427-439. DOI: 10.1080/00220272. 2015.1101618.

Seixas, Peter,. A History/Memory Matrix for History Education. Public History Weekly, 4 (2016) 6. Accessed October 31, 2016. public-history -weekly.degruyter.com/4-2016-6/a-historymemory-matrix-for-history-education/.

Shemilt, Denis. 13-16 Project Evaluation. Edinburgh: Holmes McDougall, 1980

Wineburg, Sam, Daisy Martin, and Chauncey Monte-Sano. Reading Like a Historian: Teaching Literacy in Middle and High School Classrooms. New York: Teachers College Press, 2013.

Wood, Linda Sargent. Hooked on Inquiry: History Labs in the Methods Course. History Teacher 45, no. 4 (2012): 549-567. 